\title{
IDIOM BAHASA DAWAN DIALEK AMANUBAN DI KABUPATEN TIMOR TENGAH SELATAN
}

\author{
Siti Hajar ${ }^{1}$, Heni Purniawati ${ }^{2}$ \\ FKIP, Universitas Muhammadiyah Kupang \\ siti.hajar.kamaludin@gmail.com ${ }^{1}$,henipurniawati@gmail.com ${ }^{2}$
}

\begin{abstract}
Abstrak
Bahasa Dawan merupakan bahasa yang digunakan hampir di seluruh daratan Timor atau pah meto (daratan kering). Bahasa Dawan sering disebut Uab Meto' oleh penuturnya. Bahasa Dawan masyarakat Timor Tengah Selatan (TTS) terdiri atas tiga dialek yaitu dialek Molo, Amanuban, dan Amanatun. Penelitian ini bertujuan untuk mengetahui klasifikasi idiom bahasa Dawan yang digunakan masyarakat Amanuban di Desa Falas Kecamatan Kie Kabupaten Timor Tengah Selatan. Teknik pengambilan data pada penelitian ini adalah simak catat dan wawancara. Penelitian ini menggunakan metode deskriptif kualitatif dengan pendekatan semantik. Hasil penelitian menunjukkan adanya dua jenis idiom, yakni idiom penuh dan idiom sebagian/semiidiom dengan klasifikasi idiom dengan bagian tubuh sebanyak 62, idiom dengan kata indra sebanyak 21, idiom dengan warna sebanyak 4, idiom dengan nama benda-benda alam sebanyak 11, idiom dengan nama-nama binatang sebanyak 7 , idiom dengan bagian tumbuhan sebanyak 9, dan idiom dengan kata bilangan sebanyak 8.
\end{abstract}

Kata Kunci: Idiom, Bahasa, Dawan, Amanuban

\begin{abstract}
Dawan language used in almost eastern land or pah meto society. Dawan language often called as Uab Meto' by the speakers. In dawan language society of Timor Tengah Selatan (TTS) include three dialect, they are Molo dialect, Amanuban, and Amanatun. The purpose of the paper is to know the Dawan language idiom clasification that use by Amanuban society at Falas village of kie district in Timor Tengah Selatan. The techniq data of this paper are simak catat and interview. This paper use descriptive qualitative methode with semantic approach. The result of this research shows two kinds of idiom, they are pure idioms and semi idioms with the idiom clasification such as a part of body are 62 idioms, sense of word are 21 idioms, colour idiom are 4 idioms, the name of natural things are 11 idioms, the name of animals are 7 idioms, the name of plant are 9 idioms, and the number words of idiom are 8.
\end{abstract}

Keywords: Idiom, Languange, Dawan, Amanuban

\section{PENDAHULUAN}

Bahasa Dawan merupakan bahasa yang digunakan hampir di seluruh daratan Timor atau pah meto (daratan kering). Bahasa Dawan sering disebut Uab Meto' oleh masyarakat penuturnya. Masyarakat penutur bahasa dawan dikenal sebagai atoin meto. Kata atoin berasal dari kata dasar atoni yang berarti "laki-laki", "orang", dan "manusia", 
sedangkan meto berarti "kering", maka atoin meto dapat diartikan sebagai orang-orang dari tanah (daratan) kering.

Penutur bahasa Dawan tersebar hampir di seluruh wilayah pulau Timor. Meski demikian dialek bahasa Dawan di beberapa daerah berbeda dengan daerah lain. Bahasa Dawan memiliki sepuluh dialek, yaitu Molo, Amanatun, Amanuban, Amarasi, Amfoang, Biboki, Miomafo, Manlea, Kupang dan Manulai, Tarno dalam Tenis dkk. (2018:370). Bahasa Dawan yang digunakan masyarakat Timor Tengah Selatan (TTS) memiliki tiga dialek yang digunakan baik dalam komunikasi formal maupun non-formal. Tiga dialek tersebut adalah dialek Molo, Amanuban, dan Amanatun. Bahasa Dawan dialek Amanuban digunakan di wilayah Amanuban yang meliputi Amanuban Barat, Amanuban Selatan, Amanuban Tengah, Amanuban Timur dan beberapa wilayah sekitarnya. Penutur bahasa Dawan dialek Amanuban seperti pada penutur dialek lainnya memerhatikan kesantunan berbahasa. Bahasa Dawan memiliki bahasa-bahasa kias, ungkapan atau idiom dengan kekayaan makna yang sangat beragam.

Kajian mengenai makna Chaer (2009:60) membagi jenis makna menjadi (1) makna leksikal dan makna gramatikal, (2) makna referensial dan non-referensial, (3) makna denotatif dan makna konotatif, (4) makna kata dan makna istilah, (5) makna konseptual dan makna asosiatif, (6) makna idiom dan makna peribahasa, dan (7) makna kias. Jenis makna yang menjadi fokus adalah idiom. Penjelasan mengenai idiom lebih spesifik dijelaskan Kridalaksana (2008:90), idiom adalah konstruksi dari unsur-unsur yang saling memilih, masing-masing anggota mempunyai makna yang ada hanya karena yang lain atau konstruksi yang maknanya tidak sama dengan gabungan makna anggotaanggotanya. Konstruksi unsur pembentuknya menyebabkan adanya perubahan makna yang jauh dari makna penyusunnya.

Idiom bahasa Dawan digunakan sebagai pelengkap komunikasi lisan masyarakat sekaligus untuk memperhalus bahasa. Misanya hae maputu' untuk menggambarkan seorang laki- laki atau perempuan yang istri/suaminya mati muda lalu ia menikah lagi dan istri/suami mati lagi dan seterusnya. Kata hae berarti kaki dan maputu berarti panas. Dua kata tersebut merupakan idiom yang menjelaskan makna yang jauh dari makna leksikal keduanya. Ada pula kemiripan beberapa idiom bahasa Indonesia yang sepadan artinya dengan idiom bahasa Dawan. Misalnya, keras kepala (nak fatu), darah daging (aok nesan), berat hati (nek ma'fen) dan lain-lain. Keberadaan idiom bahasa Dawan dituturkan oleh orang-orang tua sebagai kekayaan tuturan lisan yang penting untuk dituliskan sebagai sebuah upaya dokumentasi. Salah satu upaya dokumentasi bahasa Dawan dialek Amanuban adalah dengan melakukan kajian dan dokumentasi tertulis untuk mengetahui makna dan idiom bahasa Dawan yang digunakan oleh Masyarakat Amanuban di Desa Falas Kecamatan Kie Kabupaten Timor Tengah Selatan. Penelitian ini dapat dilakukan melalui proses dokumentasi dan klasifikasi idiom, penerjemahan, pemaknaan, sampai pada tahap penafsiran makna idiom bahasa Dawan yang berkembang dalam masyarakat.

Penelitian ini bertujuan untuk mengetahui jenis idiom yang digunakan masyarakat Amanuban di Desa Falas Kecamatan Kie Kabupaten Timor Tengah Selatan.

Penelitian yang berkaitan dengan idiom sudah pernah dilakukan oleh beberapa peneliti, yaitu Idiom dalam Masyarakat di Desa Pondek Tengah Kecamatan V Koto Kabupaten Muno-Muko Bengkulu Utara oleh Harlina dkk. (2012), Idiom Bahasa Melayu Dialek Sanggau oleh Trisna dkk. (2015), Idiom Bahasa Minangkabau di Daerah Lintau Buo Kecamatan Lontau Buo Kabupaten Tanah Datar oleh Isra Hidayati dkk. (2015), Analisis Korpus terhadap Idiom Bahasa Indonesia yang Berbasis Nama Binatang oleh Bagus Pragnya Paramata (2018). 
Pertama, penelitian berjudul Idiom dalam Masyarakat di Desa Pondek Tengah Kecamatan V Koto Kabupaten Muno-Muko Bengkulu Utara oleh Herlina dkk. (2012) fokus pada bahasa yang dipakai oleh suku Pondok Tengah yang mendiami kecamatan Muko-Muko Bengkulu Utara. Hasil penelitian ini menunjukkan Idiom di desa pondok tengah kecamatan V Koto Bengkulu Utara terdiri atas dua bentuk, yakni berbentuk dua kata dan tiga kata, 77 idiom terdiri atas dua kata, dan 8 idiom yang terdiri dari tiga kata, kemudian idiom dikelompokkan berdasarkan jumlah kata pembentuknya seperti bagian tubuh, nama binatang, tumbuh-tumbuhan, kata benda, kata indra.

Kedua, penelitian berjudul Idiom Bahasa Melayu Dialek Sanggau oleh Trisna dkk. (2015) fokus pada bahasa Melayu dialek Sanggau di Kalimantan Barat. Hasil penelitian menunjukkan dalam bahasa Melayu Sanggau idiom sering digunakan untuk memperindah bahasa. Idiom dalam bahasa Melayu Sanggau dapat berupa idiom penuh dan semiidiom. Bentuk idiom penuh antara lain tenak muka, penek alal, masok akal, setengoh ati, ati kocit, urang pintar, betulang paha, tolu ikan, bekoras ati, dan lain-lain. Bentuk idiom semi antara lain anak manok, tidur manok, tergigit lidah, rengkek kaeng, dan lain-lain. Kalasifikasi idiom terdiri atas tujuh bagian, yakni idiom dengan bagian utuh, idiom dengan kata indra, idiom dengan nama warna, idiom dengan benda-benda alam, idiom dengan nama binatang, idiom dengan bagian nama-nama tumbuhan, dan idiom dengan bilangan.

Ketiga, penelitian berjudul Idiom Bahasa Minangkabau di Daerah Lintau Buo Kecamatan Lontau Buo Kabupaten Tanah Datar oleh Isra Hidayati dkk. (2015), yang memfokuskan penelitian pada idiom bahasa Minangkabau. Hasil penelitian ini menunjukkan idiom yang ditemukan yakni idiom bagian tubuh dan idiom kata bilangan. Juga terdapat dua idiom, yakni idiom penuh dan idiom sebagian.

Empat, penelitian berjudul Analisis Korpus terhadap Idiom Bahasa Indonesia yang Berbasis Nama Binatang oleh Bagus Pragnya Paramata (2018), Idiom bahasa Indonesia berbasis nama binatang digunakan untuk merujuk pada manusia dan benda. Kedua jenis idiom yang muncul dalam idiom bahasa Indonesia berbasis nama binatang, yaitu pure idiom dan semi idiom. Ketiga idiom yang berbasis nama binatang digunakan untuk merujuk pada karakter negatif, positif, dan netral.

Kajian pustaka yang dilakukan dalam penelitian-penelitian di atas fokus pada idiom bahasa daerah Bengkulu, Kalimantan Barat, Minangkabau, dan bahasa Indonesia. Kajian di atas dapat memberi gambaran penggunaan idiom oleh masyarakat di beberapa tempat yang berbeda-beda. Pengembangan hasil penelitian dapat diteruskan dengan melakukan penelitian penggunaan idiom bahasa Dawan dialek Amanuban di Timor Tengah Selatan. Penelitian ini menarik sebab belum banyak peneliti yang mendokumentasikan idiom bahasa Dawan dialek Amanuban.

Definisi idiom oleh para ahli secara umum memiliki kesamaan. Idiom adalah satuan- satuan bahasa (bisa berupa kata, frasa maupun kalimat yang maknanya tidak dapat "diramalkan" dari makna leksikal unsur-unsurnya maupun makna gramatikal satuansatuan tersebut (Chaer, 2009:74). Makna satuan yang tidak dapat diramalkan terjadi sebab idiom dapat lahir sebagai arti yang baru baik berhubungan dengan kata yang menyusunnya maupun tidak berhubungan. Lebih jauh Kridalaksana (2008:90) menjelaskan idiom adalah konstruksi dari unsur-unsur yang saling memilih, masingmasing anggota mempunyai makna yang ada hanya karena yang lain atau konstruksi yang maknanya tidak sama dengan makna anggotanya. Konstruksi makna ini melahirkan makna baru yang bersifat arbiter dan jauh dari makna leksikal unsur-unsur anggotanya. 
Sejalan dengan dua pendapat di atas, Manaf (2010:62), idiom adalah makna satuan bahasa yang tidak dapat ditelusuri berdasarkan makna leksikal dan makna gramatikal leksem yang membentuknya. Makna leksikal dan makna gramatikal yang menyusunnya telah mengalami konstruksi sehingga ditemukan makna baru yang digunakan oleh masyarakat sebagai penghalus bahasa. Makna baru dari hasil konstruksi ini dapat dikatakan menyimpang dari kaidah bahasa yang umum.

Idiom menurut Suwandi, (2008:92) membagi idiom menjadi dua jenis, yakni idiom penuh dan idiom sebagian. Idiom penuh adalah idiom yang maknanya sama sekali tidak terekam atau tergambarkan dari unsur-unsurnya, seperti idiom mata gelap yang dibangun oleh kata mata dan gelap yang maknanya sangat berbeda dengan arti kata-kata yang menyusunnya. Mata gelap berarti tidak sadar akan tindakan yang sedang atau telah dilakukan. Sementara idiom sebagian/semiidiom masih tergambar makna dari unsur pembangunnya atau dengan kata lain masih tetap dalam leksikalnya. Misalnya, tutup usia yang dibangun oleh dua kata yakni tutup dan usia yang maknanya masih berhubungan dengan kata tutup. Tutup usia berarti telah kehabisan usia atau meninggal.

Selain jenis-jenis idiom yang telah digambarkan di atas, Wasrie (2012:131) membagi idiom menjadi 7 bagian, yakni idiom sebagian, idiom dengan kata indra, idiom dengan nama warna, idiom dengan nama benda-benda alam, idiom dengan nama binatang, idiom dengan bagian tumbuh-tumbuhan, dan idiom dengan kata bilangan. idiom-idiom ini dapat ditemukan penggunaannya dalam berkomunikasi, baik dalam bahasa Indonesia maupun bahasa daerah.

\section{METODE PENELITIAN}

Penelitian ini menggunakan metode deskriptif kualitatif dengan pendekatan semantik. Penggunaan metode ini difokuskan pada hubungan antar kebudayaan dengan bahasa dan penggunanya karena objek penelitian idiom bahasa Dawan masyarakat Timor. Pengumpulan data penelitian berdasarkan latar alami yang berarti semata-mata berdasarkan fakta kebahasaan yang ada. Menurut Hancock dkk. (2009:7) penelitian kualitatif berhubungan dengan membangun penjelasan tentang fenomena sosial.

Teknik pengumpulan data idiom bahasa Dawan Dialek Amanuban dilakukan dengan dua cara yakni simak catat dan wawancara. Simak dilakukan dengan cara menyimak penggunaan idiom bahasa Dawan masyarakat di Desa Falas dan mencatat temuan, sedangkan wawancara dilakukan setelah simak catat dengan menghadirkan tuatua adat Desa Falas. Wawancara dengan tua-tua adat dilakukan untuk mengetahui ungkapan-ungkapan yang belum diketahui juga mencari tahu makna idiom yang belum diketahui.

Metode penelitian menjelaskan rancangan, kegiatan, ruang lingkup atau objek, bahan dan alat utama, tempat, teknik pengumpulan data, definisi operasional variable penelitian, dan teknik analisis.

\section{HASIL DAN PEMBAHASAN}

Data yang ditemukan menunjukkan klasifikasi idiom dengan bagian tubuh sebanyak 62, idiom dengan kata indra sebanyak 21, idiom dengan warna sebanyak 4 , idiom dengan nama benda-benda alam sebanyak 11, idiom dengan nama-nama binatang sebanyak 7, idiom dengan bagian tumbuhan sebanyak 9, dan idiom dengan kata bilangan sebanyak 8. 


\section{Idiom dengan Bagian Tubuh}

Tabel 1 Data 62 idiom degan bentuk tubuh dan pemaknannya

\begin{tabular}{|c|c|}
\hline Nak Ma'fena /Kepala Berat= Mengantuk & 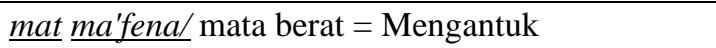 \\
\hline Lulu Mtasa /Bibir Merah= Menyirih & mata $\underline{\text { teme }} /$ mata tertutup $=$ orang lain \\
\hline 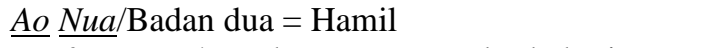 & $\underline{\text { mat }} \underline{\text { aklahat } / \text { mata meyala }=\text { nakal }}$ \\
\hline Naifa niman $/$ Pangku tangan= Malas bekerja & 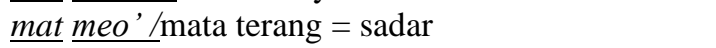 \\
\hline Ma maeke/Lidah licin = Pandai bicara/ bergosip & human pin/ wajah menyala $=$ merona \\
\hline Fefa Naek/mulut besar = Cerewet & 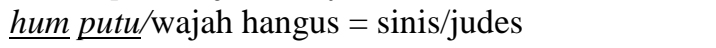 \\
\hline Loen Tuka/ Otak Pendek= Bodoh & panam 'mnutu /hidung halus= Hidung mancung \\
\hline 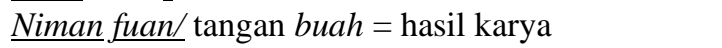 & uku niman/mengepal tangan $=$ malas kerja \\
\hline $\begin{array}{l}\text { Selo } \text { nim/campur tangan }=\text { mencampuri urusan } \\
\text { orang }\end{array}$ & $\begin{array}{l}\text { ansaonan } \\
\text { man } \text { mof /danan / ujung lidah }=\text { bicara manis }\end{array}$ \\
\hline Mat mes okan /Mata gelap = tidak sadar & $\underline{\text { man }}$ tef/ bertalian perut $=$ saudara \\
\hline Panat fefak /jaga mulut = mewas diri & pana 'mnutu' /hidung runcing = mancung \\
\hline Matnan taonon $/$ mata tertuju $=$ Suka & pan $\underline{\text { bena }}$ ' /hidung pelat $=$ pesek \\
\hline 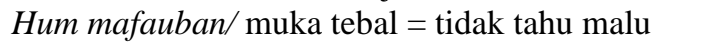 & pana mneof hidung jelas $=$ jelas \\
\hline$\frac{\text { Hae }}{\text { sesuatu }}$ maputu $/$ kaki panas $=$ tidak awet memiliki & 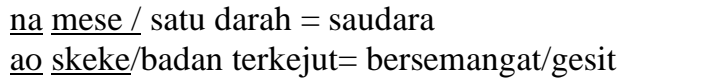 \\
\hline 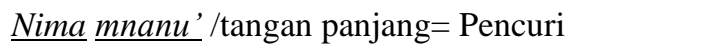 & ao makiki/ badan geli= khawatir \\
\hline Matan ikon mata ekor $=$ Sinis & sui kona'/pipi lubang = lesung pipit \\
\hline$\frac{\text { Fef }}{\text { menaseat }}$ /mulut pedas $=$ pembicaraan yang & $\begin{array}{l}\frac{n a^{\prime}}{\text { ao }} \frac{\text { nesan }}{\text { ma'fen }} / \text { darah daging }=\text { anak } \\
\text { batat }=\text { Malas bekerja }\end{array}$ \\
\hline Ansao hol /dada takut penakut & human $m e_{-}^{\prime} /$ wajah $/$ merah = malu \\
\hline Ansao mof/ dada jatuh=dada berdebar kencang & tam lonef/masuk otak $=$ logis \\
\hline $\begin{array}{l}\text { Fufun } \frac{\text { tunan } / \text { puncak ubun-ubun sesuatu yang }}{\text { menimpa seseorang }} \\
\text {. }\end{array}$ & $\begin{array}{l}\text { Ilan } \\
\text { seseorang }\end{array}$ \\
\hline$\underline{\text { Hae }} \underline{\text { mnanu }} /$ kaki panjang = Tinggi & lone $\underline{\text { mnanu }}$ otak panjang $=$ pintar \\
\hline 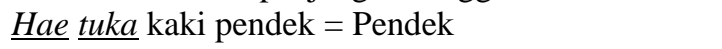 & $\underline{\text { ma }} \overline{\text { matlae }}$ /lidah bercabang= tidak dapat dipercaya \\
\hline$\underline{\text { Ansao }}$ mese dada satu = persatuan & matan fuan $/$ mata buah/biji= melihat dengan jelas \\
\hline 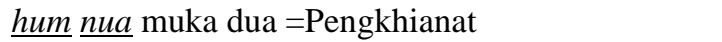 & $\underline{\text { nek }} \underline{\text { mese/hati satu }=\text { bersatu }}$ \\
\hline$\overline{\text { fefan }} \overline{\text { konan }}$ mulut lubang $=$ Cerewet & 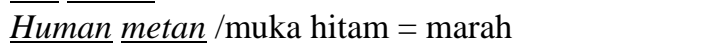 \\
\hline nak foe/kepala berulah $=$ Pemarah & naim hae /cari kaki=merusak hidup seseorang \\
\hline$\underline{\text { ao }} \underline{\text { kait/ }}$ badan bergeliat $=$ ingin & lau klulu/ gigit jari = menyesal \\
\hline aonan moen/ badan hidup $=$ sadar & $\underline{\text { nimna }}$ ' 'neo / tangan kanan = orang kepercayaan \\
\hline$\underline{\text { ao }} \underline{\text { mina }} /$ Badan enak = baik/sehat & naan sae /darah naik= emosi/marah \\
\hline nim ma'fena /tangan berat =pelit/kikir & Lonef nasnua/ otak terbalik = gila \\
\hline
\end{tabular}

Temuan data dapat dipahami pada uraian contoh pembahasan berikut:

Data 1

$\underline{\text { Loen }} \underline{\text { Tuka }}$

Otak Pendek

Bodoh

Idiom loen tuka merupakan idiom dengan nama anggota tubuh yang karena menggunakan kata loen atau lonef yang berarti otak. Idiom ini terdiri dari dua kata yaitu loen (otak) dan tuka' (pendek). Bila diterjemahkan dalam bahasa Indonesia menjadi pendek otak. Idiom ini merupakan idiom penuh karena maknanya sama sekali tidak tereka atau tergambarkan dari unsur-unsurnya. Idiom loen tuka (otak pendek) bagi masyarakat Amanuban bermakna bodoh. 
Data 2

selo nim

campur tangan

mencampuri urusan orang/ikut berpartisipasi

Idiom selo nim merupakan idiom dengan nama anggota tubuh karena menggunakan kata niman atau nima yang berarti tangan. Idiom ini terdiri dari dua kata yaitu selo (campur) dan nim (tangan). Bila diterjemahkan dalam bahasa Indonesia menjadi campur tangan. Idiom ini termasuk idiom sebagian/semiidiom karena maknanya masih tergambar dari salah satu unsurnya, yakni pada kata selo (campur). Idiom selo nim (campur tangan) bagi masyarakat Amanuban bermakna mencampuri urusan orang/ ikut berpartisipasi

Data 3

mat mesokan

mata gelap

tidak sadar

Idiom mat mesokan merupakan idiom dengan nama anggota tubuh yang karena menggunakan kata mat atau mata yang berarti mata. Idiom ini terdiri dari dua kata yaitu mat (mata) dan mesokan (gelap). Bila diterjemahkan dalam bahasa Indonesia menjadi mata gelap. Idiom ini merupakan idiom penuh karena maknanya sama sekali tidak terekam atau tergambarkan dari unsur-unsurnya. Idiom mat mesok (mata gelap) bagi masyarakat Amanuban bermakna tidak sadar.

Data 4

$\underline{\text { Hum }} \underline{\text { mafauban }}$

muka tebal

tidak tahu malu

Idiom hum mafauban merupakan idiom dengan nama anggota tubuh yang karena menggunakan kata hum yang berarti muka/wajah. Idiom ini terdiri dari dua kata yaitu hum (muka/wajah) dan mafauban (tebal). Bila diterjemahkan dalam bahasa Indonesia menjadi wajah tebal. Idiom ini merupakan idiom penuh karena maknanya sama sekali tidak tereka atau tergambarkan dari unsur-unsurnya. Idiom hum mafauban (wajah tebal) bagi masyarakat Amanuban bermakna tidak tahu malu.

Data 5

$\underline{\text { matan }} \underline{\text { ikon }}$

mata ekor

Sinis

Idiom matan ikon merupakan idiom dengan nama anggota tubuh yang karena menggunakan kata matan berarti mata. Idiom ini terdiri dari dua kata yaitu matan (mata) dan ikon (ekor). Bila diterjemahkan dalam bahasa Indonesia menjadi ekor mata. Idiom ini merupakan idiom penuh karena maknanya sama sekali tidak terekam atau tergambarkan dari unsur-unsurnya. Idiom matan ikon (ekor mata) bagi masyarakat Amanuban bermakna sinis/jutek. 


\section{Idiom dengan Bagian Kata Indra}

Tabel 2 Data 21 idiom dengan kata indra dan pemaknaannya

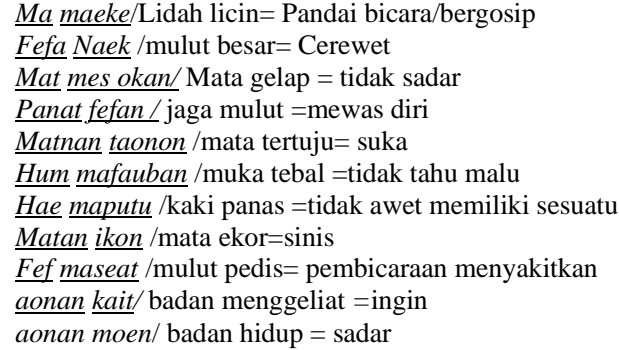

mat ma'fena / mata berat =Mengantuk

mata teme/mata tertutup bersemangat/gesit $\underline{\text { ao }}$ makiki badan geli $=$ khawatir

human me'/wajah merah $=$ malu

ma matlae /lidah bercabang = tidak dapat dipercaya

matan fuan/buah mata $=$ melihat sendiri

$\underline{\text { hana }} \underline{\text { mnutu }}$ suara halus $=$ bersuara merdu

mat aklahat $/$ mata meyala $=$ nakal

humam pin/ wajah menyala = Merona

hum putu/wajah hangus $=$ sinis/judes

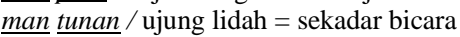
ao skeke/badan terkejut = cekatan

Temuan data dapat dipahami pada uraian contoh pembahasan berikut:

Data 1

$\underline{\text { Ma }} \underline{\text { maeke }}$

Lidah licin

Pandai bicara/bergosip

Idiom ma maeke merupakan idiom dengan menggunakan kata indra karena terdapat kata ma yang berarti lidah. Idiom ini terdiri dari dua kata yaitu ma (lidah) dan maeke (licin). Bila diterjemahkan dalam bahasa Indonesia menjadi padai bicara/. Idiom ini merupakan idiom penuh karena maknanya sama sekali tidak tereka atau tergambarkan dari unsur-unsurnya. Idiom ma maeka (pandai bicar/bergosip) bagi masyarakat Amanuban bermakna pandai bicara/bergosip.

Data 2

Fefa Naek

mulut besar

Cerewet

Idiom fefa naek merupakan idiom dengan menggunakan kata indra karena terdapat kata fefa yang berarti mulut. Idiom ini terdiri dari dua kata yaitu fefa (mulut) dan naek (besar). Bila diterjemahkan dalam bahasa Indonesia menjadi mulut besar. Idiom ini merupakan idiom penuh karena maknanya sama sekali tidak terekam atau tergambarkan dari unsur-unsurnya. Idiom fefa naek (mulut besar) bagi masyarakat Amanuban bermakna cerewet.

Data 3

Mat $\underline{\text { mesokan }}$

Mata gelap

tidak sadar

Idiom mat mesokan merupakan idiom dengan menggunakan kata indra karena terdapat kata mata yang berarti mata. Idiom ini terdiri dari dua kata yaitu mat (mata) dan mesokan (gelap). Bila diterjemahkan dalam bahasa Indonesia menjadi tidak sadar. Idiom ini merupakan idiom penuh karena maknanya sama sekali tidak terekam atau tergambarkan dari unsur-unsurnya. Idiom mat mesokan (tidak sadar) bagi masyarakat Amanuban bermakna tidak sadar. 
Data 4

Panat fefan

jaga mulut

mewas diri

Idiom panat fefan merupakan idiom dengan menggunakan kata indra karena terdapat kata fefa yang berarti mulut. Idiom ini terdiri dari dua kata yaitu panat (jaga) dan fefa (mulut). Bila diterjemahkan dalam bahasa Indonesia menjadi mewas diri. Idiom ini merupakan idiom penuh karena maknanya sama sekali tidak tereka atau tergambarkan dari unsur-unsurnya. Idiom panat fefan (jaga mulut) bagi masyarakat Amanuban bermakna mewas diri.

Data 5

Matnan taonon

mata tertuju

suka

Idiom matnan taonan merupakan idiom dengan menggunakan kata indra karena terdapat kata mata yang berarti mata. Idiom ini terdiri dari dua kata yaitu mat (mata) dan taonon (tertuju). Bila diterjemahkan dalam bahasa Indonesia menjadi mata tertuju. Idiom ini merupakan idiom penuh karena maknanya sama sekali tidak terekam atau tergambarkan dari unsur-unsurnya. Idiom matnan taonon (mata tertuju) bagi masyarakat Amanuban bermakna suka.

\section{Idiom dengan Warna}

Tabel 3 Data 4 idiom dengan warna dan pemaknaannya

$\underline{\text { mat }} \underline{\text { molo }}$ /mata kuning = suaggi

$\underline{\text { human }} \underline{m} e^{\prime} /$ wajah merah $=$ sehat

$\underline{\text { kaes }} \underline{\text { muti'/ }}$ pendatang putih= orang asing/bule

$\underline{\text { Human }} \underline{\text { metan }}$ /Muka hitam $=$ marah

Temuan data dapat dipahami pada uraian contoh pembahasan berikut:

Data 1

$\underline{\text { mat }} \underline{\text { molo }}$

mata kuning

Suanggi

Idiom mat molo merupakan idiom dengan menggunakan kata indra karena terdapat kata mat yang berarti mata. Idiom ini terdiri dari dua kata yaitu mat (mata) dan molo (kuning). Bila diterjemahkan dalam bahasa Indonesia menjadi mata kuning. Idiom ini merupakan idiom penuh karena maknanya sama sekali tidak terekam atau tergambarkan dari unsur-unsurnya. Idiom mat molo (pandai bicara/bergosip) bagi masyarakat Amanuban bermakna suanggi.

Data 2

$\underline{\text { human }} \underline{\text { me' }}$

wajah merah

sehat

Idiom human me 'merupakan idiom dengan warna karena menggunakan kata me yang berarti merah. Idiom ini terdiri dari dua kata yaitu human (muka/wajah) dan me'me 
(merah-merah). Bila diterjemahkan dalam bahasa Indonesia menjadi wajah kemerahan. Idiom ini merupakan idiom penuh karena maknanya sama sekali tidak terekam atau tergambarkan dari unsur-unsurnya. Idiom human me' (wajah kemerahan) bagi masyarakat Amanuban bermakna malu.

Data 3

kaes muti'

pendatang putih

orang asing/bule

Idiom kaes muti' merupakan idiom dengan warna karena menggunakan kata muti' yang berarti putih. Idiom ini terdiri dari dua kata yaitu kase (pendatang) dan muti' (putih). Bila diterjemahkan dalam bahasa Indonesia menjadi pendatang berkulit putih. Idiom ini merupakan idiom penuh karena maknanya sama sekali tidak tereka atau tergambarkan dari unsur-unsurnya. Idiom kaes muti (pendatang berkulit putih) bagi masyarakat Amanuban bermakna orang asing (merujuk pada orang Belanda).

Data 4

$\underline{\text { Human }} \underline{\text { metan }}$

Muka hitam

marah

Idiom human metan merupakan idiom dengan warna karena menggunakan kata metan yang berarti hitam. Idiom ini terdiri dari dua kata yaitu human (muka/wajah) dan metan (hitam). Bila diterjemahkan dalam bahasa Indonesia menjadi wajah hitam. Idiom ini merupakan idiom penuh karena maknanya sama sekali tidak tereka atau tergambarkan dari unsur-unsurnya. Idiom human metan (wajah hitam) bagi masyarakat Amanuban bermakna marah.

\section{Idiom dengan Nama Benda-Benda Alam}

Tabel 4 Data 11 idiom dengan nama benda-benda alam dan pemaknaannya

\begin{tabular}{|c|}
\hline Manas pe'/matahari pecah $=$ terbit \\
\hline$\overline{\text { Funan }}$ bol $/$ bulan muncul= bulan purnama \\
\hline Oe ktapa'/air pungut=anak yang tak jelas ayahnya \\
\hline
\end{tabular}

Temuan data dapat dipahami pada uraian contoh pembahasan berikut:

Data 1

$\underline{\text { nai }}$ maputu

tanah panas

gersang/tidak subur

Idiom nai maputu' merupakan idiom dengan menggunakan nama benda-benda alam karena terdapat kata nain yang berarti tanah. Idiom ini terdiri dari dua kata yaitu nain (tanah) dan maputu' (panas). Bila diterjemahkan dalam bahasa Indonesia menjadi tanah panas. Idiom ini merupakan idiom penuh karena maknanya sama sekali tidak terekam atau tergambarkan dari unsur-unsurnya. Idiom nai maputu (tanah panas) bagi masyarakat Amanuban bermakna gersang/tidak subur.

\author{
kana/Air nama= leluhur \\ aputu /tanah panas = gersang/ tidak subur \\ neok afu/makan abu $=$ mati \\ oe luman/air kosong = minuman tanpa kudapan
}


Data 2

nai manikin

tanah dingin

subur

Idiom nai manikin merupakan idiom dengan menggunakan nama benda-benda alam karena terdapat kata nain yang berarti tanah. Idiom ini terdiri dari dua kata yaitu nain (tanah) dan manikin (subur). Bila diterjemahkan dalam bahasa Indonesia menjadi tanah panas. Idiom ini merupakan idiom penuh karena maknanya sama sekali tidak terekam atau tergambarkan dari unsur-unsurnya. Idiom nai manikin (tanah dingin) bagi masyarakat Amanuban bermakna subur.

Data 3

lail afu

jadi abu

terlanjur

Idiom lail afu merupakan idiom dengan menggunakan nama benda-benda alam karena terdapat kata afu yang berarti $a b u$. Idiom ini terdiri dari dua kata yaitu lail (jadi) dan $a f u(a b u)$. Bila diterjemahkan dalam bahasa Indonesia menjadi jadi abu. Idiom ini merupakan idiom penuh karena maknanya sama sekali tidak terekam atau tergambarkan dari unsur-unsurnya. Idiom lail afu (jadi abu) bagi masyarakat Amanuban bermakna terlunjur hina.

Data 4

neok $\underline{a f u}$

makan abu

mati

Idiom neok afu merupakan idiom dengan menggunakan nama benda-benda alam karena terdapat kata $a f u$ yang berarti $a b u$. Idiom ini terdiri dari dua kata yaitu neok (makan) dan afu (abu). Bila diterjemahkan dalam bahasa Indonesia menjadi makan abu. Idiom ini merupakan idiom penuh karena maknanya sama sekali tidak terekam atau tergambarkan dari unsur-unsurnya. Idiom neok afu (makan abu) bagi masyarakat Amanuban bermakna mati.

Data 5

oe luman

air kosong

minuman tanpa kudapan

Idiom oe luman merupakan idiom dengan menggunakan nama benda-benda alam karena terdapat kata oe yang berarti air. Idiom ini terdiri dari dua kata yaitu oe (air) dan luman (kosong). Bila diterjemahkan dalam bahasa Indonesia menjadi iar kosong. Idiom ini merupakan idiom penuh karena maknanya sama sekali tidak terekam atau tergambarkan dari unsur-unsurnya. Idiom oe laman (air kosong) bagi masyarakat Amanuban bermakna minuman tanpa kudapan. 


\section{Idiom dengan Nama Binatang}

Tabel 5 Data 7 idiom dengan nama binatang dan pemaknannya

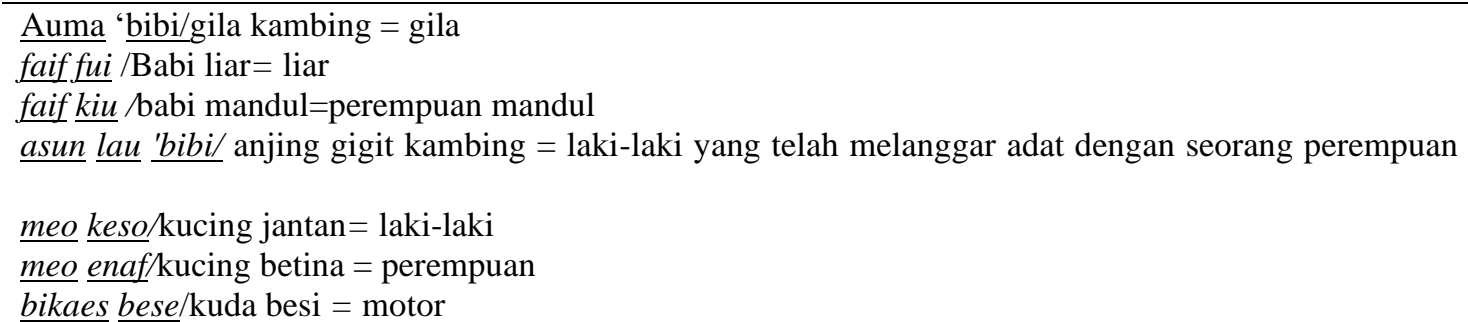

Temuan data dapat dipahami pada uraian contoh pembahasan berikut:

Data 1

faiffui

Babi liar

liar

Idiom faif fui merupakan idiom dengan menggunakan nama binatang karena terdapat kata 'fafi yang berarti babi. Idiom ini terdiri dari dua kata yaitu faif (babi) dan fui (liar). Bila diterjemahkan dalam bahasa Indonesia menjadi babi liar. Idiom ini merupakan idiom penuh karena maknanya sama sekali tidak terekam atau tergambarkan dari unsur-unsurnya. Idiom faif fui (babi liar) bagi masyarakat Amanuban bermakna orang yang jarang berkunjung.

Data 2

faif kiu

babi mandul

perempuan mandul

Idiom faif kiu merupakan idiom dengan menggunakan nama binatang karena terdapat kata 'fafi yang berarti babi. Idiom ini terdiri dari dua kata yaitu faif (babi) dan kiu (mandul). Bila diterjemahkan dalam bahasa Indonesia menjadi babi mandul. Idiom ini merupakan idiom penuh karena maknanya sama sekali tidak terekam atau tergambarkan dari unsur-unsurnya. Idiom faif kiu (babi limandular) bagi masyarakat Amanuban bermakna perempuan mandul.

Data 3

$\underline{\text { asun }} \underline{\text { lau }} \quad \underline{\text { 'bibi }}$

anjing gigit kambing

laki-laki yang telah melanggar adat dengan seorang perempuan

Idiom asu lau 'bibi merupakan idiom dengan menggunakan nama binatang karena terdapat kata 'asu yang berarti anjing dan 'bibi yang berarti kambing. Idiom ini terdiri dari dua kata yaitu asu (anjing), lau (gigit) dan 'bibi (kambing). Bila diterjemahkan dalam bahasa Indonesia menjadi Anjing menggigit kambing. Idiom ini merupakan idiom penuh karena maknanya sama sekali tidak terekam atau tergambarkan dari unsur-unsurnya. Idiom asu lau' 'bibi (anjing menggigit kambing) bagi masyarakat Amanuban bermakna laki-laki yang telah melanggar adat dengan seorang perempuan.

Data 4

$\underline{a u m a}$ bibi 
gila kambing

gila

Idiom auma; bibi merupakan idiom dengan menggunakan nama binatang karena terdapat kata 'bibi yang berarti kambing. Idiom ini terdiri dari dua kata yaitu auma (gila) dan 'bibi (kambing). Bila diterjemahkan dalam bahasa Indonesia menjadi gila kambing. Idiom ini merupakan idiom penuh karena maknanya sama sekali tidak terekam atau tergambarkan dari unsur-unsurnya. Idiom auma 'bibi (gila kambing) bagi masyarakat Amanuban bermakna gila kambuhan

Data 5

$\underline{\text { bikaes }} \underline{\text { bese }}$

kuda besi

motor

Idiom bikae bese merupakan idiom dengan menggunakan nama binatang karena terdapat kata 'bikase yang berarti kuda. Idiom ini terdiri dari dua kata yaitu mbikaseeo (kuda) dan bese (besi). Bila diterjemahkan dalam bahasa Indonesia menjadi kuda besi. Idiom ini merupakan idiom penuh karena maknanya sama sekali tidak terekam atau tergambarkan dari unsur-unsurnya. Idiom bikaes bese (kuda besi) bagi masyarakat Amanuban bermakna motor.

\section{Idiom dengan Bagian Tumbuhan}

Tabel 6 Data 9 idiom dengan bagian tumbuhan dan pemaknaannya

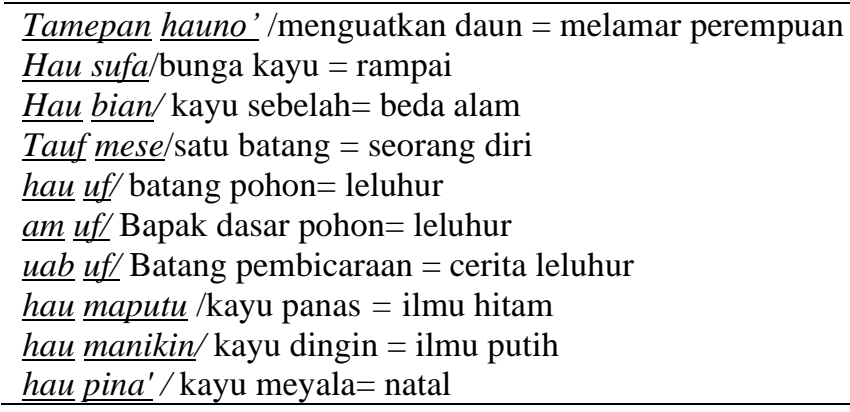

Temuan data dapat dipahami pada uraian contoh pembahasan berikut:

Data 1

$\underline{\text { Hau }} \underline{\text { sufa }}$

bunga kayu

rampai

Idiom hau sufa merupakan idiom dengan menggunakan bagian tumbuhan karena terdapat kata 'hau yang berarti kayu dan sufa yang berarti bunga. Idiom ini terdiri dari dua kata yaitu hau (kayu) dan sufa (bunga). Bila diterjemahkan dalam bahasa Indonesia menjadi buga kayu. Idiom ini merupakan idiom penuh karena maknanya sama sekali tidak terekam atau tergambarkan dari unsur-unsurnya. Idiom hau sufa (bunga kayu) rampai. 
Data 2

Hau bian

kayu sebelah

beda alam

Idiom hau bian merupakan idiom dengan menggunakan bagian tumbuhan karena terdapat kata 'hau yang berarti kayu. Idiom ini terdiri dari dua kata yaitu hau (kayu) dan bian (seberang). Bila diterjemahkan dalam bahasa Indonesia menjadi kayu seberang. Idiom ini merupakan idiom penuh karena maknanya sama sekali tidak terekam atau tergambarkan dari unsur-unsurnya. Idiom hau bian (kayu seberang) bagi masyarakat Amanuban bermakna berbeda alam.

Data 3

tauf mese

satu batang

seorang diri

Idiom tauf mese' merupakan idiom dengan menggunakan bagian tumbuhan karena terdapat kata 'tauf yang berarti batang. Idiom ini terdiri dari dua kata yaitu tauf (batang) dan mese (satu). Bila diterjemahkan dalam bahasa Indonesia menjadi satu batang. Idiom ini termasuk idiom sebagian/semiidiom karena maknanya masih tergambar dari salah satu unsurnya, yakni pada kata mese (satu). Idiom tauf mese (satu batang) bagi masyarakat Amanuban bermakna seorang diri.

Data 4

hau maputu

kayu panas

ilmu hitam

Idiom hau maputu merupakan idiom dengan menggunakan bagian tumbuhan karena terdapat kata 'hau yang berarti kayu. Idiom ini terdiri dari dua kata yaitu hau (kayu) dan maputu (panas). Bila diterjemahkan dalam bahasa Indonesia menjadi kayu panas. Idiom ini merupakan idiom penuh karena maknanya sama sekali tidak terekam atau tergambarkan dari unsur-unsurnya. Idiom hau maputu (kayu panas) bagi masyarakat Amanuban bermakna ilmu hitam.

Data 5

$\underline{\text { hau }}$ pina'

kayu meyala

natal

Idiom hau pina' merupakan idiom dengan menggunakan bagian tumbuhan karena terdapat kata 'hau yang berarti kayu. Idiom ini terdiri dari dua kata yaitu hau (kayu) dan pina' (menyala). Bila diterjemahkan dalam bahasa Indonesia menjadi kayu menyala. Idiom ini merupakan idiom penuh karena maknanya sama sekali tidak terekam atau tergambarkan dari unsur-unsurnya. Idiom hau pina' (kayu menyala) bagi masyarakat Amanuban bermakna natal. 


\section{Idiom dengan Kata Bilangan}

Tabel 7 Data 21 idiom dengan kata bilangan dan pemaknaannya

\begin{tabular}{|c|c|}
\hline $\begin{array}{l}\text { Tauf } \frac{\text { mese/satu batang }=\text { seorang diri }}{\text { Ansao mese/ satu dada=Bersatu }} \\
\text { hum } \frac{\text { nua } / \text { muka dua=pengkhianat }}{\text { nek }} \text { nuaon/ dua perasaan = bingung/ dua pilihan }\end{array}$ & $\begin{array}{l}\underline{\text { na }} \underline{\text { mese }} / \text { satu darah }=\text { saudara } \\
\underline{\text { nek }} \text { mese } / \text { satu hati }=\text { Bersatu } \\
\underline{a o} \text { nua/ Badan dua }=\text { Hamil }\end{array}$ \\
\hline
\end{tabular}

Temuan data dapat dipahami pada uraian contoh pembahasan berikut:

Data 1

Tauf $\underline{\text { mese }}$

satu batang

seorang diri

Idiom tauf mese merupakan idiom dengan menggunakan kata bilangan karena terdapat kata mese' yang berarti satu. Idiom ini terdiri dari dua kata yaitu tauf (batang) dan mese' (satu). Bila diterjemahkan dalam bahasa Indonesia menjadi satu batang. Idiom ini termasuk idiom sebagian/semiidiom karena maknanya masih tergambar dari salah satu unsurnya, yakni pada kata mese (satu). Idiom tauf mese' (satu batang/sebatang) bagi masyarakat Amanuban bermakna seorang diri.

Data 2

$\underline{\text { hum }} \underline{\text { nua }}$

muka dua

pengkhianat

Idiom hum nua' merupakan idiom dengan menggunakan kata bilangan karena terdapat kata nua' yang berarti dua. Idiom ini terdiri dari dua kata yaitu hum (muka/wajah) dan nua (dua). Bila diterjemahkan dalam bahasa Indonesia menjadi muka dua. Idiom ini merupakan idiom penuh karena maknanya sama sekali tidak terekam atau tergambarkan dari unsur-unsurnya. Idiom hum nиa (muka dua) bagi masyarakat Amanuban bermakna tidak dapat dipercaya/berkhianat.

Data 3

nek nuaon

dua perasaan

bingung/dua pilihan

Idiom nek nuaon merupakan idiom dengan menggunakan kata bilangan karena terdapat kata nua yang berarti dua. Idiom ini terdiri dari dua kata yaitu nek (perasaan) dan uaon (dua). Bila diterjemahkan dalam bahasa Indonesia menjadi dua perasaan. Idiom ini merupakan idiom penuh karena maknanya sama sekali tidak terekam atau tergambarkan dari unsur-unsurnya. Idiom nek nuaon (dua perasaan) bagi masyarakat Amanuban bermakna bingung/dua pilihan.

Data 4

na $\quad \underline{\text { mese }}$

satu darah

saudara 
Idiom na' mese merupakan idiom dengan menggunakan kata bilangan karena terdapat kata mese' yang berarti satu. Idiom ini terdiri dari dua kata yaitu na (darah) dan mese' (satu). Bila diterjemahkan dalam bahasa Indonesia menjadi satu darah. Idiom ini merupakan idiom penuh karena maknanya sama sekali tidak terekam atau tergambarkan dari unsur-unsurnya. Idiom na'mese (satu darah) bagi masyarakat Amanuban bermakna saudara.

Data 5

$\underline{a o} \quad \underline{n u a}$

Badan dua

Hamil

Idiom ao nua' merupakan idiom dengan menggunakan kata bilangan karena terdapat kata nua' yang berarti dua. Idiom ini terdiri dari dua kata yaitu ao (badan) dan nua' (dua). Bila diterjemahkan dalam bahasa Indonesia menjadi badan dua. Idiom ini merupakan idiom penuh karena maknanya sama sekali tidak terekam atau tergambarkan dari unsur-unsurnya. Idiom aо пиа (badan dua) bagi masyarakat Amanuban bermakna hamil.

\section{SIMPULAN}

Berdasarkan analisis data dan pembahasan ditemukan 7 klasifikasi idiom dalam bahasa dawan yakni idiom dengan bagian tubuh sebanyak 62, idiom dengan kata indra sebanyak 21 , idiom dengan warna sebanyak 4 , idiom dengan nama benda-benda alam sebanyak 11, idiom dengan nama-nama binatang sebanyak 7, idiom dengan bagian tumbuhan sebanyak 9, dan idiom dengan kata bilangan sebanyak 8. Selain itu ditemukan pula penggunaan idiom penuh dan idiom sebagian (semiidiom). Penggunaan idiom yang dominan dalam bahasa Dawan adalah idiom dengan batang tubuh. Idiom-idiom yang telah ditemukan merupakan idiom yang aktif digunakan masyarakat di Amanuban.

\section{DAFTAR PUSTAKA}

Chaer, A. (2009). Pengantar semantik bahasa Indonesia. Jakarta: Rineka Cipta.

Harlina, H., Juita, N., \& Emidar, E. (2012). Idiom dalam masyarakat Pondek Tengah Kecamatan Limo Koto Kabupaten Muko-muko Bengkulu Utara. Pendidikan Bahasa Indonesia, 1(1), 665-672.

Hidayati, I., \& Laili, I. (2014). Idiom bahasa Minangkabau di Daerah Lintau Kecamatan Lintau Buo Kabupaten Tanah Datar. Abstract of Undergraduate Research, Faculty of Humanities, Bung Hatta University, 1(1).

Kridalaksana, H. (2008). Kamus linguistik. Jakarta: Rineka Cipta.

Manaf, N. A. (2010). Semantik Bahasa Indonesia. Padang: UNP Press.

Paramarta, B. P. (2018). Analisis korpus terhadap idiom bahasa Indonesia yang berbasis nama binatang. Lingua, 14(1), 18-25.

Suwandi, S. (2008). Semantik pengantar kajian makna. Jakarta: Media Pustaka. 
Tenis, H. I., Kroon, Y. B., \& Haan, J. W. (2018). Peran semantis argumen klausa verbal bahasa Dawan dialek Amanuban, Nusa Tenggara Timur. SASDAYA: Gadjah Mada Journal of Humanities, 2(2), 369-392.

Trisna, I., Saman, S., \& Simanjuntak, H. (Tanpa Tahun). Idiom Bahasa Melayu Dialek Sanggau. (Doctoral dissertation, Tanjungpura University). Diakses dari https://media.neliti.com/media/publications/214134-none.pdf 